\title{
A systematic review of treatment of settling problems and night waking in young children
}

ABSTRACT Objective To assess the efficacy of treatment of settling problems and night waking in young children. Design A systematic review of randomized controlled trials of interventions. Setting Electronic bibliographic databases and references on identified papers, hand searches, and personal contact with specialists. Subjects Children aged 5 years or younger who had established settling problems or night waking. Interventions Interventions had to be described and a placebo, waiting list, or another intervention needed to have been used as a comparison. Interventions comprised drug trials or nondrug trials. Main outcome measures Number of wakes at night, time to settle, or number of nights in which these problems occurred. Results Drugs seemed to be effective in treating night waking in the short term, but long-term efficacy was questionable. In contrast, specific behavioral interventions showed both short-term efficacy and possible longer term effects for dealing with settling problems and night waking. Conclusions Given the prevalence and persistence of childhood sleep problems and the effects they can have on children and families, treatments that offer long-lasting benefits are more appealing, and these are likely to be behavioral interventions.

\section{INTRODUCTION}

Settling problems and night waking are the most common sleep problems in young children, affecting about $20 \%$ of children aged 1 to 3 years and about $10 \%$ of children aged 4.5 years. ${ }^{1-4}$ Such problems are frequently persistent and are associated with behavioral difficulties. ${ }^{2,3}$ They also adversely affect families, being linked with maternal ill health and marital discord. ${ }^{5}$

Sedation is the most frequently used therapy for childhood sleep problems, despite concerns about its effectiveness. ${ }^{6,7} \mathrm{~A}$ wide range of other interventions (usually psychological) are available, however, including behavioral programs guided by a therapist, parent educational groups, and self-help booklets. ${ }^{8-10}$ Recent reviews give different advice as to the most effective forms of treatment. ${ }^{7,11-13}$ Parents often express dissatisfaction with drugs and some behavioral treatments, such as extinction (leaving the child to cry), which can be distressing and impractical for some parents. ${ }^{14,15}$ Both professionals and parents would benefit from a greater understanding of the effectiveness of therapies for childhood sleep problems.

We aimed to assess the evidence of efficacy of therapies for settling problems and night waking in healthy young children by systematically reviewing all randomized controlled trials in this area. We considered settling problems and night waking together because they often coexist, ${ }^{2}$ and programs that target one tend to have a beneficial effect on the other.

\section{METHODS}

\section{Search protocol}

Two of us (L W and P R) independently searched for trials on MEDLINE (1966-September 1998), EMBASE

\section{Summary points}

- Settling problems and night waking are both common and can be persistent in young children

- A range of therapies exists for these problems, including various drugs and nondrug interventions (primarily behavioral)

- Drugs are effective in the short term for some children, but behavioral interventions are more likely to be effective in the short term and to have continuing benefit in the longer term immediate effect, but over a longer period, no single behavioral treatment has yet been identified as being more effective than the others

- Choice of treatment should be based on families' preferences and circumstances, because these will affect their willingness and ability to adhere to the chosen treatment

(1980-June 1998), PsychINFO (1974-September 1998), Biological Abstracts (1985-June 1998), CINAHL (Cumulative Index to Nursing and Allied Health) (1982September 1998), SIGLE (System for Information on Grey Literature in Europe) (1980-June 1998), and the Cochrane database (including the Cochrane Controlled Trials Register, issue 2, 1998). The search terms "child," "infant," "toddler," "sleep," "settling," "wake," "treatment," "medication," "therapy," and "intervention" were used, as were the names of authors. No language restrictions were applied. Available abstracts were reviewed, and suitable articles were requested, along with those that we could not judge adequately from the abstract.
- Of the behavioral interventions, extinction has a more
Paul Ramchandani Luci Wiggs

University of Oxford Section of Child and Adolescent Psychiatry Park Hospital for Children

Headington, Oxford Vicky Webb

Willen Hospice

Milton Rd

Willen Village

Milton Keynes, England Gregory Stores

University of Oxford Section of Child and Adolescent Psychiatry Park Hospital for Children

Correspondence to: Dr Ramchandani

Child and Family Psychiatry Service Sue Nicholls Centre Manor House, Aylesbury Buckinghamshire HP20 1EG, England paulgulab@aol.com

Competing interests: None declared

Funding: This work was supported in part by a bursary from the Oxford and Anglia Region Research and Development Committee (P R) and a grant 049393 from the Wellcome Trust (P R).

This article was originally published in $B M J$ 2000;320:209-213 
This search was supplemented by tracking all references in these articles and those cited in reviews, ${ }^{7,11-13}$ books, ${ }^{16,17}$ and a personal bibliography as well as handsearching the Journal of Child Psychology and Psychiatry for the past 5 years. To identify additional unpublished and published studies, we contacted authors of identified studies where possible and the current manufacturers of trimeprazine tartrate.

\section{Inclusion criteria}

We included: studies of young children (aged 5 and younger) with an established sleep problem, recognized as problematic by their parents or carers — settling problem (refusing or taking a long time to settle at night or tantrums at bedtime) or night waking (waking frequently, waking for long periods, or both); randomized controlled trials only (crossover or parallel design); studies not specifically of children with a learning disability or those with a particular physical or mental health problem; studies that described the intervention package, with placebo, waiting list, or another intervention as control; and studies with outcome measures that included number of night wakes, time to settle, or number of nights in which these problems occurred.

\section{Critical appraisal of methodologic quality}

The quality of the trials was assessed independently and in an open (nonblinded) manner by 2 of us (P R and V W), using the criteria of Jadad et al. ${ }^{18}$ Disagreements were resolved by discussion. This system considers randomization, blinding, and withdrawals (dropouts) from trials. A higher score indicates greater methodologic rigor. These criteria have high interrater reliability and good criterionrelated validity when compared with longer scoring systems. ${ }^{18}$ This system, however, only assessed the studies as described by the authors. Additional information was extracted on the number and age range of participants in each trial, the referral source, the sleep problem, the intervention and control procedures, the outcome scores and measures, and measurement times.

\section{RESULTS}

Overall, 44 studies were located. Ten of these were thought to meet the inclusion criteria, but 1 could not be appraised fully because it did not contain sufficient detail of the methods. Nine studies were finally included: 4 on drugs, ${ }^{14,19-21} 4$ on behavioral treatments (1 also with a booklet component), $, 10,15,22$ and 1 on a general nondirective educational approach (delivered by booklet). ${ }^{23}$ It would have been inappropriate to perform a meta-analysis because of the heterogeneity of the subjects, treatments, and outcome measures.

\section{Methodologic quality}

There was initial agreement between the assessors $78 \%$ of the time. The average quality score of the trials was low (2.1). The mean quality score of the trials of behavioral treatment was lower than the drug trials $(1.6[\mathrm{SD}, 0.6]$ vs $2.8[1.3])$.

\section{Drug trials}

Table 1 gives the details of the trials. The drugs used were trimeprazine tartrate and niaprazine. Two trials were of drug only versus placebo-either up to $60 \mathrm{mg}$ or 90 mg. ${ }^{14,19}$ Both showed a significantly beneficial effect of drug treatment in the short term $(P<0.01$ and $P<0.001$, respectively). The clinical significance is less clear because in both trials, even the children on active treatment continued to wake at night, and as much as a third did not improve with drugs. The results are less convincing concerning a longer lasting effect. The same 2 studies included a follow-up period. ${ }^{14,19}$ In Richman's study, the sleep score dropped marginally from 12.4 at baseline to 10.1 at 6 months' follow-up. ${ }^{14}$ A third of the subjects, however, had withdrawn from the study at this stage. In the study by Simonoff and Stores, which had a shorter follow-up, the number of wakes at night was reduced from 2.8 at baseline to 1.6 at 4 weeks' follow-up. ${ }^{19}$ Because both studies were of a crossover design, there was no matched untreated group with which to compare these rates.

The 2 other drug trials require separate consideration. Montanari et $\mathrm{al}^{20}$ compared 2 different drugs for sleep problems and found them broadly comparable, although niaprazine (an antihistamine) was marginally better than chlordesmethyldiazepam for night waking. France et $\mathrm{al}^{21}$ used trimeprazine as an adjunct to an extinction program (ignoring a child's crying), rather than as the primary treatment. Although trimeprazine (plus extinction) did reduce night waking during the first 10 days of the trial more than placebo (plus extinction), there was no difference between the 2 groups at the end of treatment and at 4 weeks' follow-up.

\section{Nondrug trials}

Table 2 details the nondrug trials. Several techniques were used in the studies.

\section{Positive routines}

A 20-minute winding-down bedtime routine was established, initially close to the time that the child fell asleep, 
Table 1 Randomized controlled trials of drug treatment of children's sleep problems

\begin{tabular}{|c|c|c|c|c|c|}
\hline Study & $\begin{array}{l}\text { Children, No., } \\
\text { and problems }\end{array}$ & $\begin{array}{l}\text { Intervention } \\
\text { (dose) }\end{array}$ & Controls & Outcomes & Results \\
\hline Richman, $1985^{14}$ & $\begin{array}{l}\text { 22, aged } 12-24 \mathrm{mo}, \\
\text { recruited from } \\
\text { community } \\
\text { survey, with night } \\
\text { waking }\end{array}$ & $\begin{array}{l}\text { Trimeprazine } \\
\text { tartrate (30-60 } \\
\text { mg) }\end{array}$ & Placebo & $\begin{array}{l}\text { Sleep disturbance } \\
\text { score (number of } \\
\text { night wakes and } \\
\text { settling) }\end{array}$ & $\begin{array}{l}12.1 \text { with placebo; } \\
8.6 \text { with } \\
\text { treatment }(P< \\
\text { o.01) }\end{array}$ \\
\hline $\begin{array}{l}\text { Simonoff and } \\
\text { Stores, } 1987^{19}\end{array}$ & $\begin{array}{l}\text { ro, aged } 12-36 \text { mo, } \\
\text { referred for } \\
\text { study, with night } \\
\text { waking }\end{array}$ & $\begin{array}{r}\text { Trimeprazine } \\
\text { (45-90 mg) }\end{array}$ & Placebo & $\begin{array}{l}\text { Night waking } \\
\text { (frequency and } \\
\text { duration) }\end{array}$ & $\begin{array}{l}2.4 \text { wakes per night } \\
\text { with placebo; } 1.4 \\
\text { wakes per night } \\
\text { with treatment }(P \\
<0.001)\end{array}$ \\
\hline France et al, $1991^{21}$ & $\begin{array}{l}\text { 30, aged 7-27 mo, } \\
\text { referred to sleep } \\
\text { program with } \\
\text { sleep disturbance }\end{array}$ & $\begin{array}{l}\text { Extinction plus } \\
\text { trimeprazine ( } 30 \\
\mathrm{mg} \text { ) }\end{array}$ & $\begin{array}{l}\text { Extinction plus } \\
\text { placebo }\end{array}$ & $\begin{array}{l}\text { Night waking } \\
\text { (frequency and } \\
\text { duration) }\end{array}$ & $\begin{array}{l}\text { Intervention group } \\
\text { improved quicker } \\
\text { than placebo } \\
\text { group }(P<0.01) ; \\
\text { no difference } \\
\text { shown in longer } \\
\text { term }\end{array}$ \\
\hline $\begin{array}{l}\text { Montanari et al, } \\
1992^{20}\end{array}$ & $\begin{array}{l}\text { 6o, aged 1-36 mo, } \\
\text { selected from } \\
\text { pediatric } \\
\text { outpatients, with } \\
\text { sleep disturbance }\end{array}$ & Niaprazine & $\begin{array}{l}\text { Chlordesmethyl- } \\
\text { diazepam }\end{array}$ & $\begin{array}{l}\text { Night waking } \\
\text { (frequency) }\end{array}$ & $\begin{array}{l}\text { Control group: } 23 \text { of } \\
26(88 \%) \\
\text { improved; } \\
\text { intervention } \\
\text { group: } 26 \text { of } 26 \\
\text { (100\%) improved } \\
\text { (difference not } \\
\text { significant) }\end{array}$ \\
\hline
\end{tabular}

that was brought forward by 5 to 10 minutes per week to an appropriate bedtime. After the routine was completed, any resistance from the child was dealt with by parents saying "It's time for sleep" and placing the child back in bed if necessary.

\section{Graduated extinction}

Parents ignored bedtime tantrums for preset time intervals, the duration of which increased each week. At the end of the interval, parents entered the room, put the child back in bed if necessary, and told child it was time for sleep before leaving the room again after a maximum of 15 seconds.

\section{Scheduled wakes}

After the collection of baseline data, parents were instructed to wake their child 15 to 60 minutes before the child usually woke spontaneously and to resettle them to sleep in their usual manner. The number and timing of scheduled wakes were modified on a semiweekly basis, depending on the child's sleep patterns during the previous few nights.

\section{Extinction or systematic ignoring}

Parents went to their children when they were first heard to cry, checked that they were not ill, changed diapers in the crib if necessary but did not pick them up, soothe, interact, or feed them in any way. Once reassured that the child was not ill, parents left the room and did not return for the duration of that crying episode. Further crying episodes each night were dealt with in the same way.

\section{Modified extinction}

Modified extinction involved ignoring the child for 20 minutes, then checking that the child was not ill, but the parents did not pick up, soothe, interact, or feed the child. Having reassured themselves, parents left the room and returned only after the child had displayed a settling problem or night waking for a further 20 minutes. This 20minute checking interval was maintained throughout treatment. "Support visits," used in conjunction with modified extinction, consisted of a visit from the therapist every 2 or 3 days during the first 3 weeks of treatment.

\section{Educational booklet}

An educational booklet gave parents general information about children's sleep, described the advantages and disadvantages of the range of therapies for children's sleep problems, and emphasized that there was no 1 solution. Supportive visits, used in conjunction with the booklet, consisted of nondirective discussion with an untrained counselor about the child's sleep. 
Table 2 Randomized controlled trials of psychological treatments

\begin{tabular}{|c|c|c|c|c|c|}
\hline Study & $\begin{array}{l}\text { Children, No., } \\
\text { and problems }\end{array}$ & Interventions & Controls & Outcomes & Results \\
\hline $\begin{array}{l}\text { Rickert and } \\
\text { Johnson, } \\
1988^{15}\end{array}$ & $\begin{array}{l}\text { 33, aged 6-54 mo, } \\
\text { recruited through } \\
\text { newspaper ads, } \\
\text { with night waking }\end{array}$ & $\begin{array}{l}\text { Scheduled wakes or } \\
\text { extinction }\end{array}$ & Sleep diary only & $\begin{array}{l}\text { No. of night wakes } \\
\text { per week }\end{array}$ & $\begin{array}{l}5 \text { with scheduled wakes; } 2 \\
\text { with extinction; } 8 \text { with } \\
\text { controls; both } \\
\text { interventions better } \\
\text { than control }(P<0.05)\end{array}$ \\
\hline $\begin{array}{l}\text { Scott and } \\
\text { Richards, } \\
1990^{23}\end{array}$ & $\begin{array}{l}\text { 90, aged } 1-18 \mathrm{mo} \text {, } \\
\text { referred for } \\
\text { study, with night } \\
\text { waking }\end{array}$ & $\begin{array}{l}\text { Boolket and support } \\
\text { visits or booklet } \\
\text { only }\end{array}$ & Sleep diary only & $\begin{array}{l}\text { No. of night wakes } \\
\text { per night }\end{array}$ & $\begin{array}{l}1.7 \text { with both types of } \\
\text { intervention; } 1.9 \text { with } \\
\text { control; no difference } \\
\text { between treatment } \\
\text { groups or control }\end{array}$ \\
\hline $\begin{array}{l}\text { Adams and } \\
\text { Rickert, } \\
1989^{8}\end{array}$ & $\begin{array}{l}\text { 36, aged } 18-48 \text { mo, } \\
\text { recruited through } \\
\text { newspaper ads, } \\
\text { with settling } \\
\text { problems }\end{array}$ & $\begin{array}{l}\text { Positive routines or } \\
\text { graduated } \\
\text { extinction }\end{array}$ & Sleep diary only & $\begin{array}{l}\text { No. of bedtime } \\
\text { tantrums per } \\
\text { week } \\
\text { (frequency and } \\
\text { duration) }\end{array}$ & $\begin{array}{l}\text { 1/wk with both } \\
\text { interventions; } 3 / \text { wk } \\
\text { with controls; both } \\
\text { interventions better } \\
\text { than control }(P<0.001)\end{array}$ \\
\hline $\begin{array}{l}\text { Pritchard and } \\
\text { Appleton, } \\
1988^{22}\end{array}$ & $\begin{array}{l}\text { 31, aged } 9-42 \text { mo, } \\
\text { referred for } \\
\text { study, with night } \\
\text { waking and } \\
\text { settling }\end{array}$ & $\begin{array}{l}\text { Modified extinction } \\
\text { program and } \\
\text { support visits }\end{array}$ & $\begin{array}{l}\text { Modified } \\
\quad \text { extinction } \\
\text { program only }\end{array}$ & $\begin{array}{l}\text { No. of night wakes } \\
\text { per night }\end{array}$ & $\begin{array}{l}\text { No difference between } \\
\text { groups; both showed } \\
\text { reduced night waking }\end{array}$ \\
\hline $\begin{array}{l}\text { Seymour et } \\
\quad \text { al, } 1989^{10}\end{array}$ & $\begin{array}{l}\text { 45, aged } 9-60 \text { mo, } \\
\text { attenders at } \\
\text { family counseling } \\
\text { agency with sleep } \\
\text { problem }\end{array}$ & $\begin{array}{l}\text { Sleep program } \\
\text { (behavioral advice } \\
\text { booklet and } \\
\text { support) or } \\
\text { behavioral advice } \\
\text { booklet only }\end{array}$ & Waiting list & $\begin{array}{l}\text { No. of night wakes } \\
\text { per week }\end{array}$ & $\begin{array}{l}6.9 \text { with sleep program, } \\
4.9 \text { with booklet only, } \\
\text { and } 11.7 \text { with control; } \\
\text { both interventions } \\
\text { better than control }(P< \\
0.05\end{array}$ \\
\hline
\end{tabular}

\section{Sleep program}

Sleep programs consisted of an individually tailored behavioral program (using a variety of techniques that were also described in the accompanying booklet) with initially daily support telephone calls that decreased in frequency over time, accompanied by a behavioral advice booklet. The booklet contained advice about the importance of consistent bedtime routines, the need to reward appropriate nighttime behavior, and specific ways of removing parental attention at bedtime or during night wakings.

\section{Results}

Both scheduled wakenings and extinction reduced night waking compared with a control group in the trial conducted by Rickert and Johnson. ${ }^{15}$ Extinction seemed marginally more effective than scheduled wakenings, although it was unacceptable to some parents. Adams and Rickert found that both positive routines and graduated extinction were effective for settling problems. ${ }^{8}$ The outcomes of the 2 treatment groups did not differ significantly, but both compared favorably with the outcome of the control group.

Pritchard and Appleton failed to show any effect of adding additional support (in the form of visits) to their modified extinction program. ${ }^{22}$ However, the modified extinction procedure, with or without this support, resulted in large reductions in night waking over the course of the trial. Unfortunately, there was no untreated control group with which to compare the results.

Similarly, Seymour et al found no effect of adding telephone support to their trial of a booklet giving specific advice about behavioral techniques. ${ }^{10}$ However, the booklet, with or without the telephone support, showed superior outcome compared with the waiting list. In contrast, the study examining a nondirective educational booklet failed to show any benefit over a control procedure. ${ }^{23}$

Three of the trials provided follow-up data for either 6 weeks ${ }^{8,15}$ or 3 months $^{10}$ after treatment. All 3 showed that treatment effects had been maintained, although only $2^{8,15}$ were able to compare with a control procedure because the control group in the study by Seymour et $\mathrm{al}^{10}$ went on to receive the intervention. The effect of positive routines and graduated extinction on settling problems was maintained, with parents continuing the treatments, where necessary, over this time. ${ }^{8}$ The effect was similarly maintained by both scheduled wakening and extinction for night waking. ${ }^{15}$ There are some methodologic concerns with this longer term follow-up data because no information was given about numbers dropping out of the study during follow-up, and only a small number took part in the trials. The data, however, are suggestive of continuing clinically significant treatment effects for these particular behavioral interventions. 


\section{DISCUSSION}

Overall, drug treatment seemed to be a comparatively effective short-term measure for some children, but specific behavioral treatments were more likely to have both shortand longer term efficacy.

There seems to be evidence that drugs are effective in the short-term treatment of night waking in young children (particularly trimeprazine, 30-90 mg nightly). Evidence of a long-term effect, however, is only patchy and contradictory, showing that, rather than a cure, it should be viewed as an effective short-term intervention. Perhaps it is particularly useful as a relief for parents before or while embarking on other forms of treatment. The problems of adverse effects, such as daytime drowsiness, raised by France et $\mathrm{al}^{21}$ and parental resistance to giving drugs to their child are also important issues. ${ }^{24}$

In contrast, the results show that some nondrug interventions may be effective in both the short term and the longer term. Both a positive routine program and graduated extinction produced a benefit for settling problems compared with no treatment. Extinction and scheduled wakening had a beneficial effect on night waking compared with control groups. Extinction seems to have achieved clinically useful effects more quickly. All these treatments maintained their effectiveness in the longer term (up to 6 weeks), offering an important advantage when compared with the use of drugs. France et al showed no long-term benefit of adding drugs to a behavioral program such as extinction, but noted less night waking initially when it was used. ${ }^{21}$ This may increase the acceptability of extinction to some parents and suggests that there may be a role for novel combinations of approaches, not necessarily with a view to increasing efficacy but perhaps addressing issues such as compliance and acceptability to parents.

Specific behavioral advice in a written form, as with conventional delivery guided by a therapist, had a beneficial effect on a night-waking group compared with a waiting-list control group. ${ }^{10} \mathrm{~A}$ nondirective educational approach with a booklet was ineffective, even though the written material was combined with supportive visits from an untrained counselor. This suggests that the content of any advice, rather than the method of delivery, may be the more important predictor of effectiveness.

\section{CONCLUSION}

Conclusions drawn from our review should be considered tentative because most trials conducted thus far have been small and the methodologic quality (particularly of the nondrug trials) generally poor. The possibility of a positive publication bias should be considered. The acceptability to parents and children of the various interventions (which would influence compliance and outcome) is not fully addressed by our study. It can be concluded, however, that a variety of treatment options are available to health care professionals when faced with the common problem of childhood sleep problems. Trimeprazine treatment is an effective short-term option, but longer term and probably greater overall benefit is likely to be achieved by the use of psychological treatments. These are the treatment of choice for parents. The lack of an obviously most effective behavioral program or method of delivery shows that further research is necessary to evaluate the various treatments (or combination of treatments) for this common and often distressing problem. Because there is no single psychological treatment more clearly efficacious than the others, the choice of treatment needs to be based on families' preferences and particular circumstances.

The initial part of this study was undertaken by P R and submitted as a requirement for the University of Oxford postgraduate certificate in evidence-based health care. Some of the preliminary data were presented at a meeting of the Royal College of Psychiatrists Faculty of Child and Adolescent Psychiatry in September 1998. We thank Mrs Janet Harris (course director of the Oxford masters program in evidence-based health care) and Ben Thornley for helpful advice and encouragement during the early stages of this work. Contributors: P R and VW conceived the idea for the study, which was developed along with L W and G S. L W and P R undertook the literature searches, and P R and V W critically appraised the studies. P R and L W wrote the initial draft of the manuscript, to which all 4 authors contributed. P R and L W will act as guarantors for the paper.

\section{References}

1 Richman N, Stevenson JE, Graham PJ. Prevalence of behaviour problems in 3-year-old children: an epidemiological study in a London borough. J Child Psychol Psychiatry 1975;16:277-287.

2 Richman N. A community survey of characteristics of one- to two-year-olds with sleep disruptions. J Am Acad Child Psychiatry 1981;20:281-291.

3 Zuckerman B, Stevenson J, Bailey V. Sleep problems in early childhood: continuities, predictive factors, and behavioral correlates. Pediatrics 1987;80:664-671.

4 Bax MCO. Sleep disturbance in the young child. BMJ 1980;141:1177-1179.

5 Chavin W, Tinson S. Children with sleep difficulties. Health Visit 1980;53:477-480.

6 Ounsted MK, Hendrick AM. The first-born child: patterns of development. Dev Med Child Neurol 1977;19:446-453.

7 France KG, Hudson SM. Management of infant sleep disturbance: a review. Clin Psychol Rev 1993;13:635-647.

8 Adams LA, Rickert VI. Reducing bedtime tantrums: comparison between positive routines and graduated extinction. Pediatrics 1989;84:756-761.

9 Szyndler J, Bell G. Are groups for parents of children with sleep problems effective? Health Visit 1992;65:277-279.

10 Seymour FW, Brock P, During M, Poole G. Reducing sleep disruptions in young children: evaluation of therapist-guided and written information approaches: a brief report. J Child Psychol Psychiatry 1989;30:913-918.

11 Kerr S, Jowett S. Sleep problems in pre-school children: a review of the literature. Child Care Health Dev 1994;20:379-391.

12 Stores G. Practitioner review: assessment and treatment of sleep disorders in children and adolescents. J Child Psychol Psychiatry 1996;37:907-925.

13 Anders TF, Eiben LA. Pediatric sleep disorders: a review of the past 10 years. J Am Acad Child Adolesc Psychiatry 1997;36:9-20. 
14 Richman N. A double-blind drug trial of treatment in young children with waking problems. J Child Psychol Psychiatry 1985;26:591-598.

15 Rickert VI, Johnson CM. Reducing nocturnal awakening and crying episodes in infants and young children: a comparison between scheduled awakenings and systematic ignoring. Pediatrics 1988;81:203-212.

16 Douglas J, Richman N. My Child Won't Sleep. London: Penguin; 1984

17 Ferber R. Solve Your Child's Sleep Problem. New York: Simon \& Schuster; 1985.

18 Jadad AR, Moore RA, Carroll D, et al. Assessing the quality of reports of randomized clinical trials: is blinding necessary? Control Clin Trials 1996;17:1-12.

19 Simonoff EA, Stores G. Controlled trial of trimeprazine tartrate for night waking. Arch Dis Child 1987;62:253-257.
20 Montanari G, Schiaulini P, Covre A, Steffan A, Furlanut M. Niaprazine vs chlordesmethyldiazepam in sleep disturbances in pediatric outpatients. Pharmacol Res 1992;25(suppl 1):83-84.

21 France KG, Blampied NM, Wilkinson P. Treatment of infant sleep disturbance by trimeprazine in combination with extinction. Dev Behav Pediatr 1991;12:308-314.

22 Pritchard AA, Appleton P. Management of sleep problems in pre-school children. Early Child Dev Care 1988;34:227-240.

23 Scott G, Richards MPM. Night waking in infants: effects of providing advice and support for parents. J Child Psychol Psychiatry 1990;31:551-567.

24 Paul FM. Sleep disturbance in young children. Singapore Fam Physician $1982 ; 8: 111-113$ 